\title{
Processes of Late Cretaceous to Late Miocene episodic thrust-sheet translation in the Lycian Taurides, SW Turkey
}

\author{
ALAN S. COLLINS ${ }^{1} \&$ ALASTAIR H. F. ROBERTSON \\ Department of Geology \& Geophysics, University of Edinburgh, Edinburgh EH9 3JW, UK \\ ${ }^{1}$ Present address: Department of Geology, University of Leicester, LeicesterLE1 7RH, UK (e-mail: asc3@le.ac.uk)
}

\begin{abstract}
The Lycian Taurides of SW Turkey consist of an allochthonous Mesozoic passive margin succession that was episodically detached from its autochthon and translated southeastwards between latest Cretaceous to Late Miocene times. A combination of structural analysis, sedimentology, palaeontology and geochemistry allows subdivision of this orogenic event into: (1) latest Cretaceous trench-passive margin collision causing ophiolite obduction and detachment of the Köyceğiz Thrust Sheet; (2) Mid-Late Eocene continent-continent collision renewing southeastwards thrusting and causing detachment of the Teke Dere Thrust Sheet and Yavus Thrust Sheets; (3) Miocene extensional collapse of the orogen with southeastwards translation of the allochthon coeval with rift-basin formation in the hinterland.
\end{abstract}

Keywords: Turkey, Lycian Taurus, thrust sheets, extension, orogeny.

The systematic identification of tectonic units within a structurally complex region has long been used to identify lithological units that possess similar geological histories (e.g. Vedder et al. 1985). For example, by utilizing sedimentology, geochemistry and palaeontology a series of tectonic facies can be identified within tectonically bound units of an orogen (Robertson 1994). In many cases relationships of the individual tectonic units in time and space can be explained by plate tectonic processes (Şengör \& Dewey 1990), opening the way to a palinspastic reconstruction. When the displacement relationships between the units are taken into account (e.g. kinematic evidence) a reconstruction of the tectonic history of the root zone and amalgamation of the orogen becomes possible.

Here we focus on a classic Mediterranean area, the Lycian Allochthon of southwest Turkey (Graciansky 1967, 1972), that exemplifies the deformation history of an orogen from initial ophiolitic emplacement through to continent-continent collision and subsequent orogenic collapse. Similar processes operate in many orogenic belts (e.g. Alps and Caledonides), but preservation of some tectonic units in such areas is often meagre owing to tectonic deformation, burial or erosion. As a result, vital aspects such as the location of root zones, timing and mode of emplacement are often controversial (e.g. ophiolite emplacement during collision in the Himalayas; Reuber et al. 1987; Searle et al. 1987, 1997; Robertson \& Degnan 1993; Khan et al. 1997). The main importance of the Lycian Allochthon is that it is exceptionally well exposed and preserves all parts of the tectonic stack, together with welldated syn-tectonic sediments. Evidence for passive-margin development and evolution, ophiolite obduction, continentcontinent collision and extensional collapse are all found within the thrust belt. To the best of our knowledge, the Lycian Allochthon is unique in the eastern Mediterranean region in having this extensive, well-preserved, deformation record. Other, orogenic units in the region show a similar range of processes, but are commonly more fragmentary (e.g. Orthis Mountains, Greece, Smith et al. 1975; Pindos Mountains, Greece, Jones \& Robertson 1991; Pontides, north
Turkey, Ustaömer \& Robertson 1994; Karakaya Complex, west Turkey, Pickett \& Robertson 1996; Robertson et al. 1996).

Southwest Turkey consists of a series of dominantly carbonate rock thrust sheets forming the Lycian Allochthon that tectonically overlie relatively autochthonous rocks, both to the northwest and the southeast (Graciansky 1972; Poisson 1977; Gutnic et al. 1979; Collins 1997; Figs 1 \& 2). In the northwest, a metamorphosed sequence of Proterozoic to Eocene metasediments and metagranites is deformed into an elliptical dome to form the Menderes Metamorphic Complex (Dürr 1975; Dürr et al. 1978; Hetzel 1995; Hetzel et al. 1995). The highest metamorphic grades are preserved within the core of this dome (Dürr 1975). To the southeast, the Lycian Allochthon is thrust over autochthonous, unmetamorphosed, platform sediments of the Bey Dağları Unit.

Below, we first outline the tectono-stratigraphy and age relations of each of the units within the Lycian Taurides, and demonstrate a regional-scale coherence within this part of the orogen. We then discuss the tectonic development, including ophiolite emplacement, sequential thrusting and orogenic collapse. We present a well-constrained plate-tectonic model that also explains a number of regionally controversial problems (e.g. location of root zones) that are vital for an understanding of the closure of this part of Tethys.

This work is the first field based study that encompasses the whole Lycian region. As such it has built upon important local studies by a number of workers (e.g. Graciansky 1972; Poisson 1977; Şengör et al. 1984; Şenel et al. 1989; Okay 1989; Özkaya 1990, 1991; Hetzel 1995; Ersoy 1990, 1997). Table 1 compares the conclusions of this study with those of the main previous studies.

\section{Tectonic units}

Previously, parts of the Lycian Taurides were mapped as a number of thrust units as summarized in Table 1. However, at this stage little attempt was made to correlate between different areas and set up a tectonostratigraphy of the area. To try to 

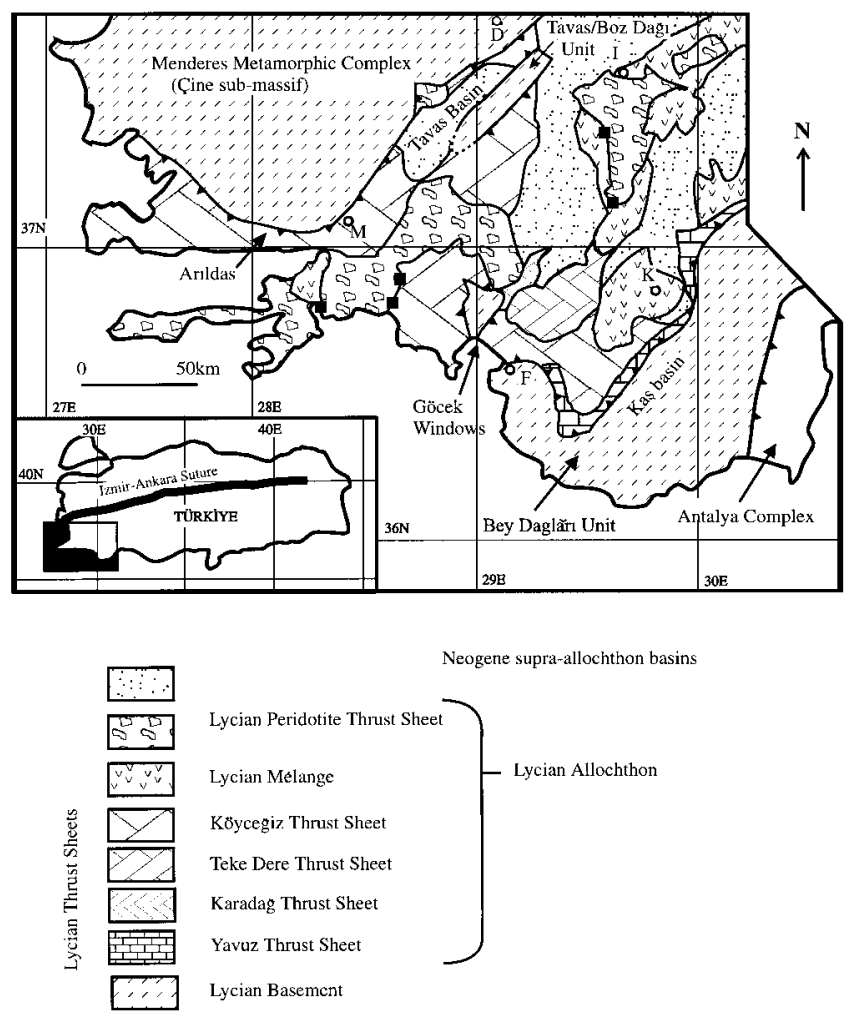

Fig. 1. Tectonostratigraphic map of the Lycian Taurides (after Collins 1997 and Collins \& Robertson 1997). Black squares mark places where the mineral lineations in Fig. $11 \mathrm{~b}$ were measured. F, Fethiye; M, Muğla; D, Denizli; I, Inçeler; K, Közağacı.

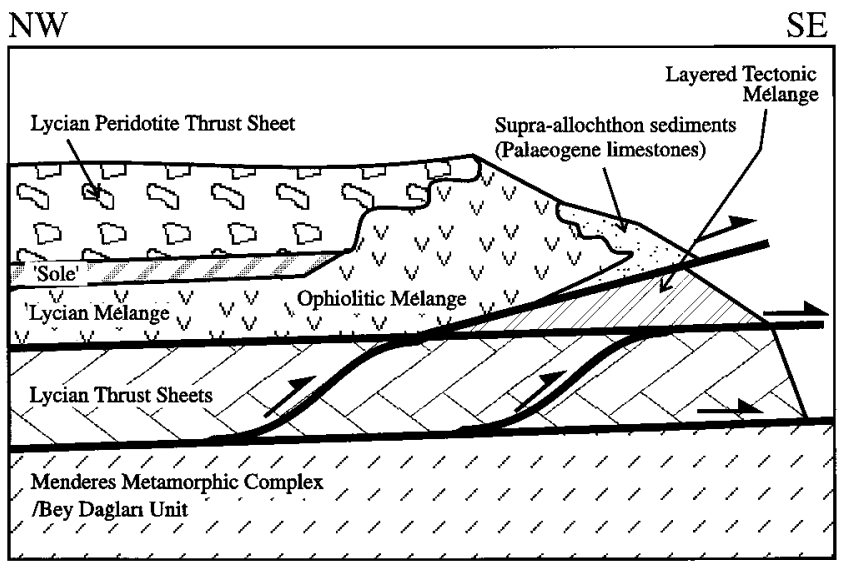

Fig. 2. Rock-relations diagram for tectonic units within the Lycian Taurides.

create a meaningful tectonic framework and link the work of earlier workers, the following subdivision of the Lycian Taurides was proposed by Collins (1997) and Collins \& Robertson (1995, 1997; Figs 1 \& 2). In ascending tectonostratigraphic order this is as follows: (1) the Lycian Basement formed of the Menderes Metamorphic Complex and the Bey Dağları Unit and representing an extensive parautochthonous unit; (2) the Lycian Thrust Sheets, dominantly carbonate thrust sheets capped by bedded radiolarites, shales and volcaniclastic sedimentary rocks of Late Palaeozoic to Oligocene age, including Eocene clastic sedimentary rocks (i.e. Yavus Thrust Sheet); (3) the Lycian Mélange, consisting of a thick $(<2 \mathrm{~km})$ chaotic unit of ocean-related sedimentary and igneous lithologies (Collins \& Robertson 1997); (4) the Lycian Peridotite Thrust Sheet, mainly serpentinized peridotite with an amphibolitic metamorphic sole; and (5) Supra-allochthon sediments, transgressive on the Lycian Mélange. The first four structural units are separated by major thrusts, whereas the fourth and fifth are separated by a regionally significant unconformity (Fig. 2).

The Mesozoic and Cenozoic stratigraphy of each of these units is outlined below with occasional reference to preMesozoic lithologies to aid interpretation. Special attention is given to the time period between latest Cretaceous and Late Miocene during which the Lycian Allochthon was emplaced from the Neotethys ocean and then translated progressively southeastwards to its present position.

\section{Lycian Basement}

The Menderes Metamorphic Complex is dissected into three segments by large east-west-trending grabens. Within the southern segment (the Cine submassif; Fig. 1), Proterozoic granites (Şengör et al. 1984; Kröner \& Şengör 1990; Hetzel \& Reischmann 1996) are overlain by Neoproterozoic/Palaeozoic schists and marbles that pass upwards into Mesozoic platform metacarbonate rocks. The metacarbonate rocks contain emery horizons that were interpreted by Dürr (1975) and Dürr et al. (1978) to represent periods of subaerial exposure. Although, discrete thrusts have been recognized within the complex (Dora et al. 1995; Hetzel 1995), suggested displacements are significantly lower than the minimum displacement of $70 \mathrm{~km}$ for the Lycian Allochthon (Hayward 1984).

The higher levels of the Menderes Metamorphic Complex (Fig. 3) preserve Upper Cretaceous limestones containing rudists (i.e. large bivalves), overlain by coarse intrabasinal limestone debris-flow deposits and micritic limestones (paticularly well seen at Arrldas, Fig. 1). These deposits show a gradual upward transition over $20 \mathrm{~m}$ into thin- to mediumbedded calc-turbidites, interbedded with pelagic limestones that contain the planktonic foraminifera Globotruncana sp. and thinly bedded shale horizons. These limestones, in turn, pass up into a distinctive sequence of purple/maroon siliceous marbles (with spot-like hematite accumulations), white granular marbles and thinly bedded (millimetre scale) phyllites (with occasional limestone debris-flow deposits). These deposits then pass abruptly into fine lithic arenites and olive-coloured shales with lenticular limestone breccias. The arenites contain the benthic foraminifera Nummulites sp. indicating an Eocene age (Konak et al. 1987). The intensity of deformation, manifest by disturbed bedding and foliation development, increases stratigraphically upwards over $c .150 \mathrm{~m}$ culminating in a calcareous mylonite that forms the base of the Lycian Allochthon.

An outlier of the Menderes Metamorphic Complex occurs east of the Tavas Basin (the Tavas/Boz Dağ1 Unit; Gutnic et al. 1979; Okay 1989; Fig. 1). This tectonic window forms an elongate structural culmination in which unmetamorphosed limestones, debris-flow deposits and lithic arenites lie beneath overthrust lithologies of the Lycian Thrust Sheets (Fig. 1). The Tavas/Boz Dağı Unit shows a very similar stratigraphy to the Menderes Metamorphic Complex (Fig. 3), suggesting that the two units originated in the same tectonic setting.

The Bey Dağlarl Unit consists of Lower Jurassic to Aquitanian (Lower Miocene) shallow-water limestones, overlain by Burdigalian to Tortonian (Lower-Upper Miocene) lithic 
Table 1. Comparison of main conclusions of this study with those of four major previous works

\begin{tabular}{|c|c|c|c|c|c|}
\hline & This work & $\begin{array}{c}\text { Graciansky } \\
(1972)\end{array}$ & $\begin{array}{c}\text { Poisson } \\
\text { (1977) }\end{array}$ & $\begin{array}{l}\text { Okay } \\
(1989)\end{array}$ & $\begin{array}{c}\text { Özkaya } \\
\text { (1990) }\end{array}$ \\
\hline Basement & $\begin{array}{l}\text { Bey Dağları and } \\
\text { the Menderes } \\
\text { Metamorphic } \\
\text { Complex }\end{array}$ & Identified Göcek Windows & $\begin{array}{l}\text { Identified that the } \\
\text { Bey Dağları was } \\
\text { overthrust from NW }\end{array}$ & $\begin{array}{l}\text { Noted the } \\
\text { parautochthonous } \\
\text { nature of the } \\
\text { Menderes } \\
\text { Metamorphic } \\
\text { Complex }\end{array}$ & $\begin{array}{l}\text { Bey Dağları and the } \\
\text { Menderes Metamorphic } \\
\text { Complex as separate } \\
\text { units }\end{array}$ \\
\hline Thrust sheets & $\begin{array}{l}\text { Four identifiable } \\
\text { thrust sheets of an } \\
\text { imbricated passive } \\
\text { margin; translated } \\
\text { episodically } \\
\text { southeastwards }\end{array}$ & $\begin{array}{l}\text { Five séries within the } \\
\text { allochthon; derived from } \\
\text { the NW }\end{array}$ & $\begin{array}{l}\text { Identified the Yavus } \\
\text { Thrust Sheet; } \\
\text { suggested a southern } \\
\text { origin for some } \\
\text { thrust sheets }\end{array}$ & $\begin{array}{l}\text { Derived from the } \\
\text { NW and overthrust } \\
\text { during a series of } \\
\text { events }\end{array}$ & $\begin{array}{l}\text { Derived from } \mathrm{N} \text { and } \\
\mathrm{S} \text { of the Menderes } \\
\text { Metamorphic Complex }\end{array}$ \\
\hline Ophiolite & $\begin{array}{l}\text { Marginal basin } \\
\text { lithosphere, derived } \\
\text { from the north, } \\
\text { obducted in the } \\
\text { Late Cretaceous }\end{array}$ & Derived from $\mathrm{N}$ & Derived from $\mathrm{N}$ & Derived from $\mathrm{N}$ & Derived from $\mathrm{N}$ \\
\hline
\end{tabular}

\section{Menderes Metamorphic Massif a) Tavas/ Boz Dağ ${ }_{l}$ Unit} b) Cine Sub-massif

NW

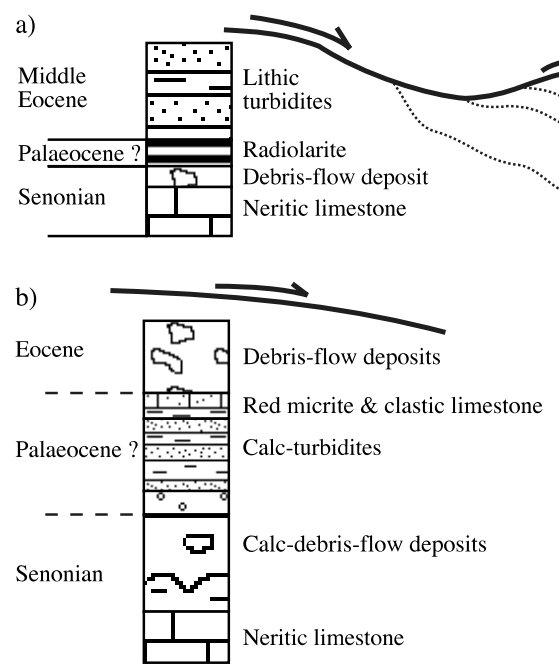

Göcek Window

Bey Dagları Unit

Fig. 3. Lithological relationships between outcrops of the Lycian Basement rocks.

arenites and shales (Fig. 3; Poisson 1977; Gutnic et al. 1979; Farinacci \& Köylüoğlu 1982; Hayward 1984). Older rocks are not exposed but are presumed to exist at depth. These autochthonous sediments are tectonically overlain by EoceneOligocene-aged rocks of the Yavus Thrust Sheet at their eastern margin. This thrust sheet represents the lowermost Lycian Thrust Sheet (Figs 2 \& 4). Hayward (1984) documented a marked increase in sediment thickness within the Middle
Miocene succession of the Bey Dağları Unit, as a foreland basin developed in front of the advancing Lycian Allochthon.

A tectonic window through the Lycian Allochthon occurs to the north of the village of Göcek (Göcek Windows; Fig. 1). The rocks within this consist of Eocene shallow-water limestones, succeeded by a depositional hiatus (marked by a disconformity) overlain by Lower Miocene rocks (Fig. 3). The youngest sediments, at Göcek, consist of Langhian (Middle 


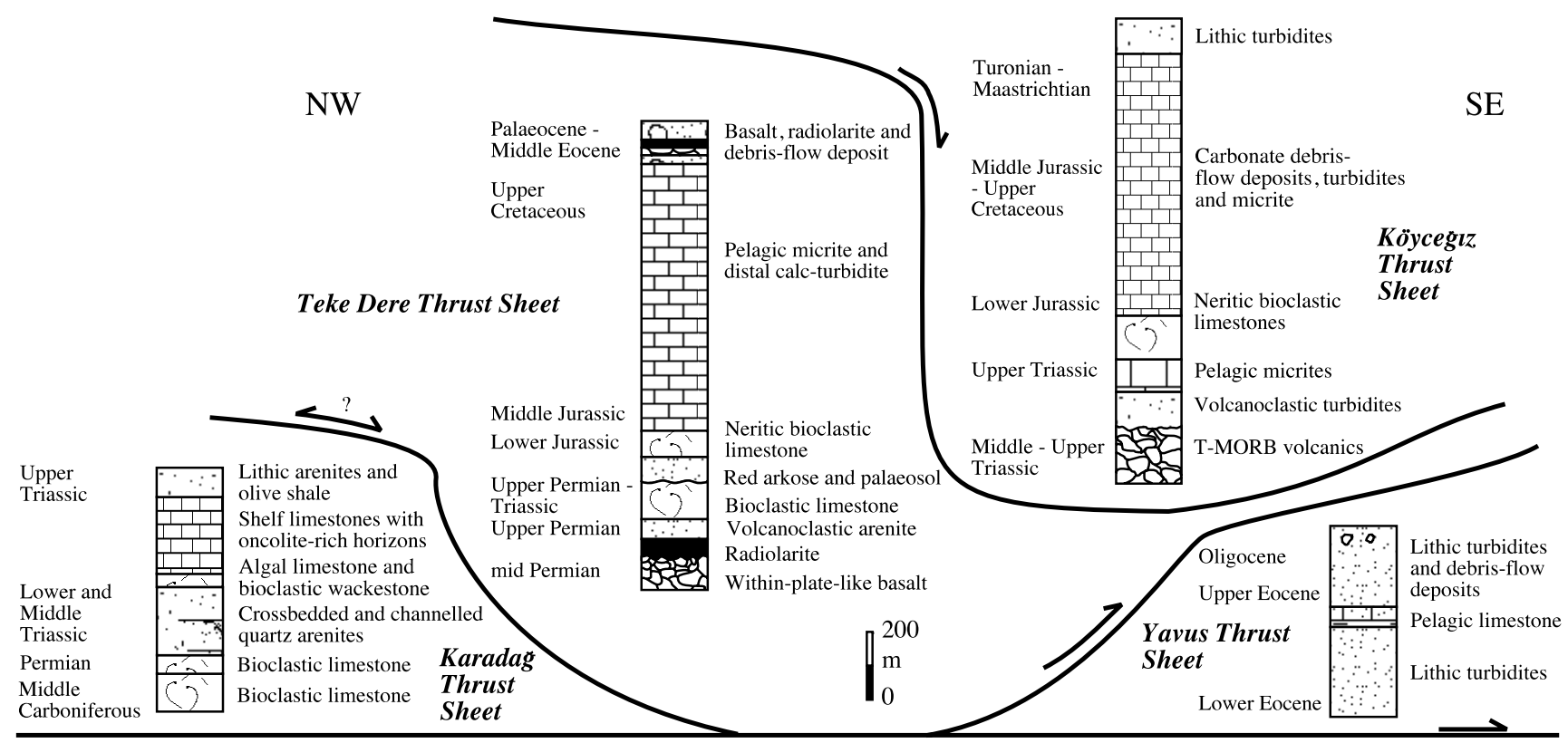

The Lycian Autochthon

Fig. 4. Stratigraphic and structural relationships between the four Lycian Thrust Sheets.

Miocene) lithic clastics, rich in grains of chrome spinel and basic volcanic rock.

In this work, we correlate the Menderes Metamorphic Complex and the Bey Dağları Unit as a single, laterally continuous, basement beneath the Lycian Allochthon throughout the study area. This is due to the following reasons: (1) the overthrust relationship of the Lycian Allochthon to both the Menderes Metamorphic Complex and the Bey Dağları Unit; (2) a similar Mesozoic succession of shallow-water limestones in both units; (3) and a diachronous age of final deposition that is explained by a southeastwards propagating thrust pile.

\section{Lycian Thrust Sheets}

A series of thrusted units overlie both the Menderes Metamorphic Complex and the Bey Dağları Unit. The structurally lower members of this allochthon consists of four coherent thrust slices of Upper Palaeozoic to Palaeogene sedimentary and volcanic rocks. These lithologies range in metamorphic grade up to lower greenschist facies and show little deformation within individual thrust sheets. Figure 4 shows the present structural relationships. Of the four thrust sheets, the Karadağ Thrust Sheet consists solely of Palaeozoic and Triassic lithologies and preserves no evidence for later tectonosedimentary events, thus, it is not discussed further here. The other three thrust sheets are summarized below, starting with the structurally lowest unit.

The Yavus Thrust Sheet crops out directly above the autochthonous Bey Dağları Unit (Fig. 1). It is only preserved in frontal parts of the allochthon and comprises lithic arenites, olive-coloured shales and thin micritic limestones (Fig. 4). The presence of the benthic foraminifera, Nummulites perforatus, Nummulites uroniensis and Discocyclina archiaci dates these rocks as Lutetian (Middle Eocene) (Poisson 1977; Gutnic et al. 1979).
The Teke Dere Thrust Sheet is thrust over the Yavus Thrust Sheet in frontal areas of the allochthon (Fig. 4). The oldest rocks within this thrust sheet are Permian volcanic rocks and syn-rift sedimentary rocks, overlain by Lower Triassic shallowwater limestones (Graciansky 1972). The succession continues with deeper-water calc-turbidites and minor debris-flow deposits of Jurassic and Cretaceous age (Graciansky 1972; Collins 1997). Palaeocene pelagic limestones overlie this succession, dated by planktonic foraminifera, including Globorotalia sp. (Şenel 1991), and are, in turn, covered by Eocene lithic arenites containing volcanic grains (biostratigraphy based on benthic foraminifera including Nummulites sp. and Alveolina sp., Şenel 1991; Özkaya 1991). The youngest rocks preserved are ophiolite-derived conglomerates, lithicarenites and intercalated flows of basaltic pillow-lavas.

Whole-rock geochemical analysis of the Eocene basaltic rocks reveals that some of them have an appreciable enrichment in incompatible high field strength elements relative to average normal mid-ocean-ridge basalt (N-MORB, Pearce 1983; Fig. 5). A plot of $\mathrm{Zr}$ versus $\mathrm{Zr} / \mathrm{Y}$ reveals a MORB-related fractionation trend (Fig. 5b; Pearce \& Norry 1979). The range of high-field-strength element compositions from MORB-like to appreciable enrichment relative to MORB, suggests either that the parental magma formed by low-degrees of partial melting of a MORB-like source, or that crustal contamination played a significant role in the evolution of the parent magma.

The Köyceǧiz Thrust Sheet differs from the structurally underlying Teke Dere Thrust Sheet, both in its pre-Jurassic and Upper Cretaceous lithologies (Fig. 4). There are no rocks older than Triassic within the Köyceğiz Thrust Sheet. The lowest lithologies preserved are pillow basalts that have geochemical compositions transitional between MORB and within-plate basalt (Collins 1997). However, the Upper Triassic to Lower Cretaceous lithologies are very similar to those of the underlying Teke Dere Thrust Sheet (Fig. 4). Ubiquitous calcturbidite successions are overlain by decimetre-bedded lithic 


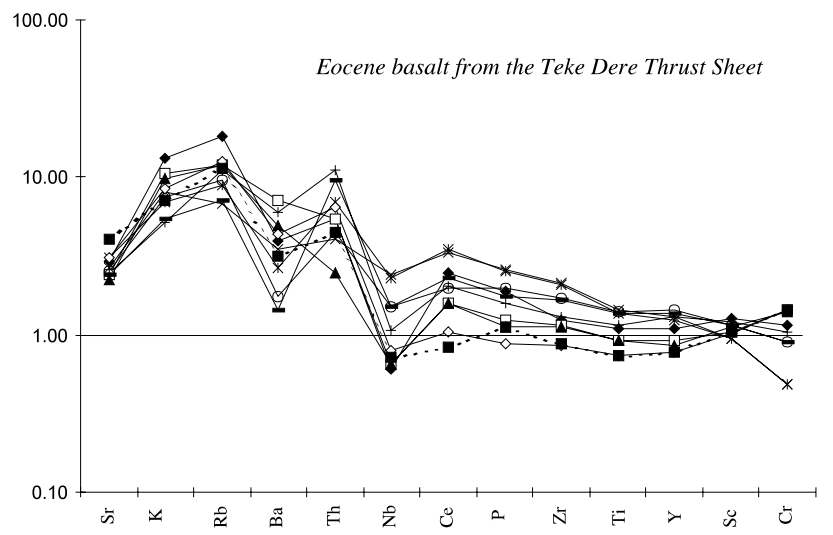

(a)

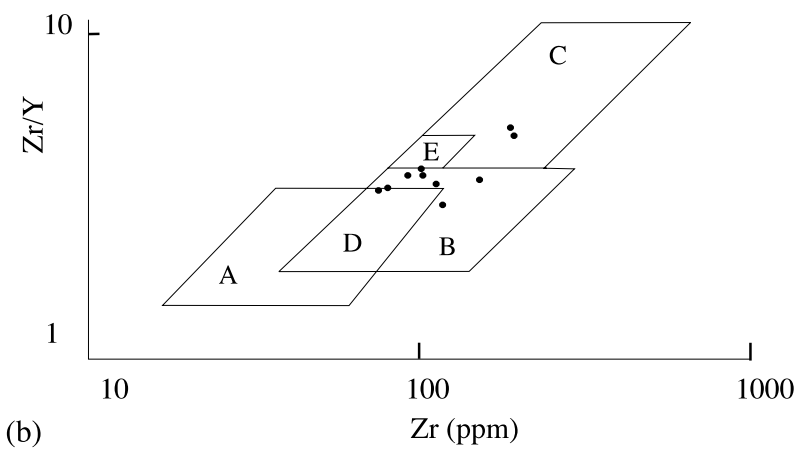

Fig. 5. Geochemical plots of selected Eocene basalts from upper levels of the Teke Dere Thrust Sheet (data from Table 2). (a) MORB-normalized incompatible element diagram (normalizing values from Pearce 1983); (b) $\mathrm{Zr}$ versus $\mathrm{Zr} / \mathrm{Y}$ diagram (Pearce \& Norry 1979): A, volcanic-arc basalt; B, MORB; C, within-plate basalt; D, MORB and volcanic-arc basalt; E, MORB and within-plate basalt.

arenites of Turonian age, dated by planktonic foraminifera, including Globotruncana convexa (Graciansky 1972). This transition is lithologically similar to that which occurs within Palaeogene rocks in the Teke Dere Thrust Sheet. The succession continues with lithic turbidites interbedded with radiolarian-rich chert and pelagic limestone of Turonian to Maastrichtian age. The succession culminates with widespread deposition of a coarse debris-flow deposit containing large blocks $(<10 \mathrm{~m})$ of Maastrichtian-aged limestone, this is dated by planktonic foraminifera including Globotruncana stuarti and $G$. arca (Graciansky 1972).

\section{The Lycian Mélange}

The Lycian Mélange is divided into two sub-units: the Layered Tectonic Mélange and the Ophiolitic Mélange (see Collins \& Robertson 1997 for further details). The former consists of slab-like inclusions of recrystallized pelagic limestone within a highly sheared matrix of lithic arenite, olive-coloured shale and red and black chert. The Ophiolitic Mélange is a $2-3 \mathrm{~km}$ thick amalgam of neritic and pelagic limestone, radiolarian-rich chert, serpentinite, amphibolite and basalt within a matrix of pervasively-sheared shale, conglomerate and lithic-arenite. The mélange has experienced very low-grade metamorphism in

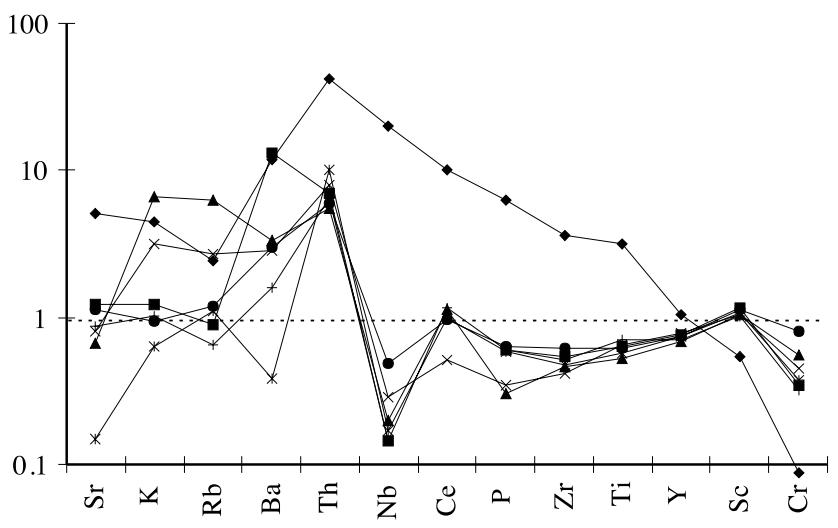

(a)

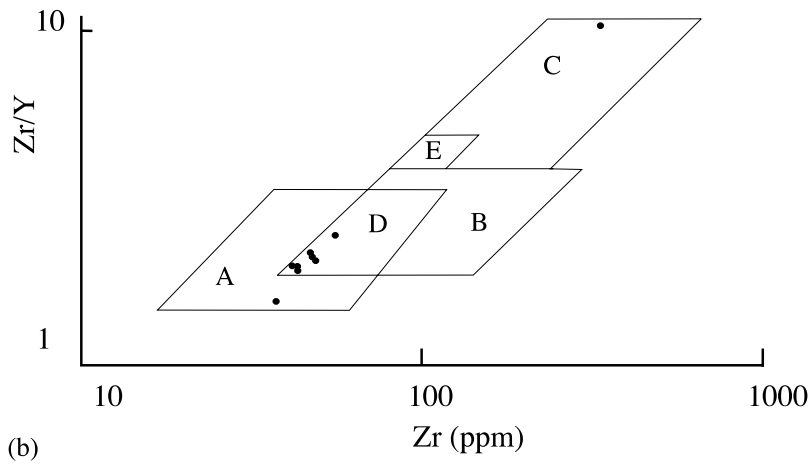

Fig. 6. Geochemical plots of selected basalt inclusions from the Ophiolitic Mélange (data from Table 2; after Collins \& Robertson 1997), highlighting a dual populations of supra-subduction zone-type and within-plate-type basalts. (a) MORB-normalized incompatible element diagram (normalizing values from Pearce 1983); (b) Zr versus $\mathrm{Zr} / \mathrm{Y}$ diagram of the analyses used in (a) (Pearce \& Norry 1979): A, volcanic-arc basalt; B, MORB; C, within-plate basalt; D, MORB and volcanic-arc basalt; E, MORB and within-plate basalt.

frontal regions, rising to lower greenschist facies towards the northwest (Collins \& Robertson 1997).

Geochemical analysis of basaltic inclusions from the Ophiolitic Mélange shows the presence of two compositional groups. One group exhibits immobile trace element characteristics suggestive of a supra-subduction zone setting (see Pearce et al. 1984), with minor depletion in the high-field strength (HFS) elements relative to average N-MORB and marked niobium depletion. A second set is enriched in these (HFS) elements relative to average N-MORB and shows within-plate affinities on tectonic discrimination diagrams (Fig. 6).

\section{The Lycian Peridotite Thrust Sheet}

The Lycian Peridotite Thrust Sheet forms an extensive outcrop ( $>4500 \mathrm{~km}^{2} ;<2 \mathrm{~km}$ thick) within the Lycian Taurides (Fig. 1). It is dominantly serpentinized harzburgite, with minor pyroxenite, podiform dunite and chromitite (Kaaden 1959; Graciansky 1967; Engin \& Hirst 1970; Collins 1997). These lithologies are cut by a suite of dolerite dykes, exhibiting chilled margins and local metasomatic calcic alteration (i.e. rodingitization). 


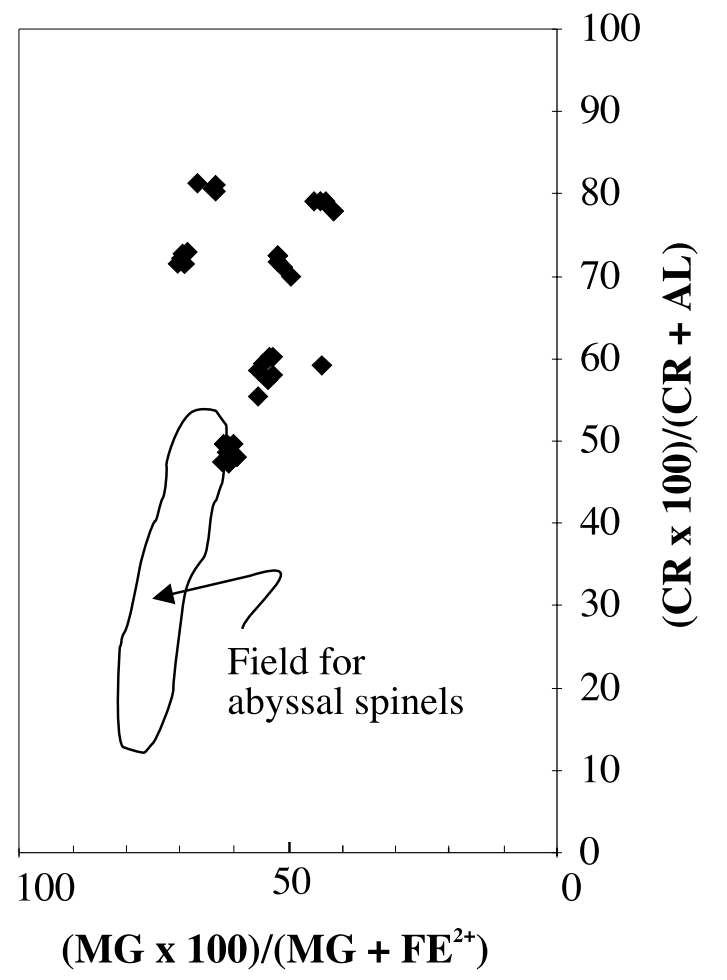

Fig. 7. Chrome spinel compositions from peridotite and chromitite within the Lycian Peridotite Thrust Sheet (data from Collins 1997), plotted on a magnesium number versus chromium number diagram (after Dick \& Bullen 1984). Chrome spinels analysed on a Cameca Camebax electron microprobe at the University of Edinburgh, operated at a $20 \mathrm{kv}$ accelerating potential and a beam current of 20 па.

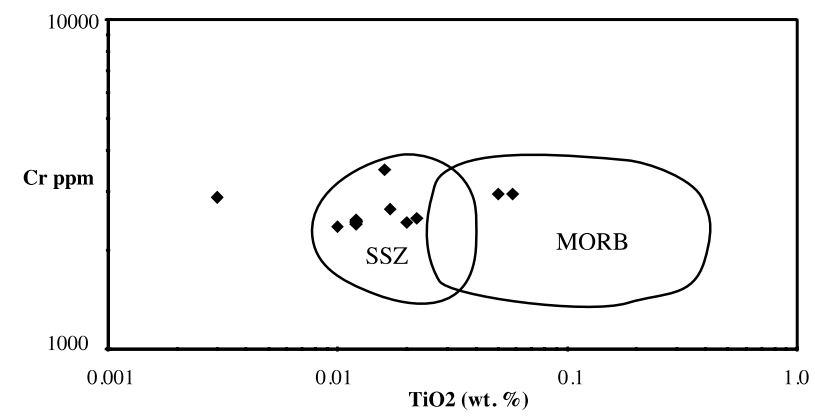

Fig. 8. Diagram comparing whole-rock $\mathrm{TiO}_{2}(\mathrm{wt} \%)$ and $\mathrm{Cr}(\mathrm{ppm})$ compositions from partially serpentinized peridotites (Pearce et al. 1984) within the Lycian Peridotite Thrust Sheet (data from Collins 1997).

Chrome-spinel grains within both the harzburgite and podiform chromitites are enriched in chromium relative to aluminium (Fig. 7). These grains are similar in composition to chrome spinels found in present-day island-arc volcanic rocks, and in ophiolites of inferred supra-subduction zone origin (e.g. Oman ophiolite; Dick \& Bullen 1984). Such high chromium values imply that large degrees of partial-melting were extracted from the Lycian peridotite resulting in concentration of compatible chromium relative to incompatible aluminium within the spinel structure (Dick \& Bullen 1984). Whole-rock analysis of selected peridotite samples (Table 3) shows that chromium and titanium contents of the Lycian peridotite are more similar to peridotites formed in supra-subduction zone settings rather than to abyssal peridotites (Fig. 8; Pearce et al. 1984). In addition, immobile trace element compositions of cross-cutting dolerite dykes (Table 3) are similar to suprasubduction zone basalt (Fig. 9).

Table 2. Selected XRF analyses of samples from basalt inclusions within the Ophiolitic Mélange

\begin{tabular}{lrrrrrrrrrrrrr}
\hline Sample & $\mathrm{Sr}$ & $\mathrm{K}_{2} \mathrm{O}$ & $\mathrm{Rb}$ & $\mathrm{Ba}$ & $\mathrm{Th}$ & $\mathrm{Nb}$ & $\mathrm{Ce}$ & $\mathrm{P}_{2} \mathrm{O}_{5}$ & $\mathrm{Zr}$ & $\mathrm{TiO}_{2}$ & $\mathrm{Y}$ & $\mathrm{Sc}$ & $\mathrm{Cr}$ \\
\hline D15B & 606.20 & 0.67 & 4.80 & 234.40 & 8.30 & 70.50 & 102.10 & 0.76 & 328.70 & 4.73 & 31.50 & 21.60 & 22.20 \\
3S20C & 145.20 & 0.18 & 1.80 & 262.40 & 1.40 & 0.50 & -0.60 & 0.07 & 48.40 & 0.94 & 22.90 & 46.20 & 85.80 \\
3S21Q & 80.20 & 0.98 & 12.60 & 66.50 & 1.10 & 0.70 & 11.40 & 0.04 & 41.40 & 0.79 & 20.50 & 41.50 & 139.00 \\
3S21S & 97.50 & 0.47 & 5.40 & 56.70 & 1.60 & 1.00 & 5.10 & 0.04 & 37.40 & 0.98 & 23.40 & 41.50 & 111.60 \\
3S21G1 & 17.60 & 0.09 & 2.20 & 7.70 & 2.00 & 0.60 & 9.90 & 0.07 & 43.10 & 0.87 & 22.00 & 42.80 & 93.50 \\
B15A & 134.10 & 0.14 & 2.40 & 59.80 & 1.20 & 1.70 & 9.70 & 0.08 & 55.80 & 0.93 & 22.30 & 45.40 & 199.20 \\
4S13B & 104.00 & 0.15 & 1.30 & 31.90 & 1.30 & 0.50 & 11.70 & 0.07 & 46.70 & 1.07 & 21.30 & 40.30 & 79.80 \\
& & & & & & & & & & & & & \\
\hline
\end{tabular}

All values in ppm except $\mathrm{K}_{2} \mathrm{O}, \mathrm{P}_{2} \mathrm{O}_{5}$ and $\mathrm{TiO}_{2}$ which are in $\mathrm{wt} \%$.

Table 3. Selected XRF analyses of samples from upper levels of the Teke Dere Thrust Sheet

\begin{tabular}{|c|c|c|c|c|c|c|c|c|c|c|c|c|c|}
\hline Sample & $\mathrm{Sr}$ & $\mathrm{K}_{2} \mathrm{O}$ & $\mathrm{Rb}$ & $\mathrm{Ba}$ & $\mathrm{Th}$ & $\mathrm{Nb}$ & $\mathrm{Ce}$ & $\mathrm{P}_{2} \mathrm{O}_{5}$ & $\mathrm{Zr}$ & $\mathrm{TiO}_{2}$ & $\mathrm{Y}$ & $\mathrm{Sc}$ & $\mathrm{Cr}$ \\
\hline $4 \mathrm{~S} 8 \mathrm{~B}$ & 350.20 & 2.00 & 36.10 & 79.60 & 1.10 & 2.10 & 24.50 & 0.23 & 112.00 & 1.64 & 32.50 & 51.40 & 290.40 \\
\hline $4 \mathrm{~S} 20 \mathrm{~B}$ & 322.40 & 1.21 & 13.70 & 69.40 & 0.80 & 8.40 & 33.60 & 0.31 & 192.60 & 2.14 & 38.90 & 37.30 & 122.00 \\
\hline $4 \mathrm{~S} 20 \mathrm{C}$ & 374.30 & 1.05 & 17.80 & 52.80 & 1.40 & 8.10 & 34.70 & 0.30 & 188.30 & 2.07 & 37.10 & 37.60 & 121.30 \\
\hline $4 \mathrm{~S} 20 \mathrm{D}$ & 160.70 & 0.31 & 5.60 & 28.90 & 2.70 & 3.20 & 9.90 & 0.13 & 90.10 & 1.26 & 24.50 & 38.40 & 328.40 \\
\hline $3 \mathrm{~S} 5 \mathrm{~L}$ & 291.70 & 0.81 & 14.20 & 28.60 & 1.90 & 5.30 & 22.80 & 0.21 & 151.50 & 2.05 & 41.40 & 46.10 & 224.70 \\
\hline $3 \mathrm{~S} 24 \mathrm{~B}$ & 373.90 & 1.28 & 25.20 & 87.30 & 1.30 & 2.80 & 10.50 & 0.10 & 76.10 & 1.11 & 23.00 & 40.60 & 359.10 \\
\hline $3 \mathrm{~S} 24 \mathrm{C}$ & 487.70 & 1.07 & 22.90 & 62.60 & 0.90 & 2.50 & 8.40 & 0.13 & 79.10 & 1.12 & 23.00 & 41.20 & 361.70 \\
\hline
\end{tabular}




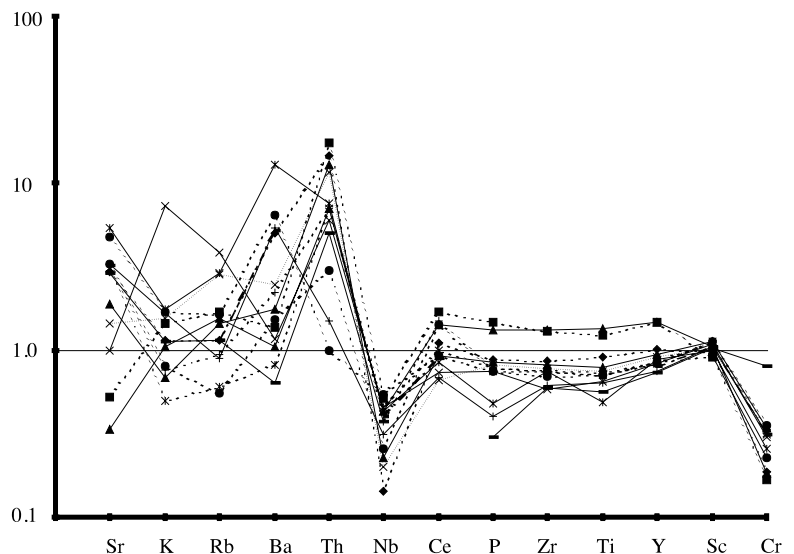

Fig. 9. MORB-normalized multi-element diagram dolerite samples that occur as dykes cutting peridotite of the Lycian Peridotite Thrust Sheet (data from Table 4; normalizing values from Pearce 1983).

A metamorphic sole of variable thickness (locally up to $500 \mathrm{~m}$ ) directly underlies the peridotite thrust sheet. These rocks consist of pervasively sheared and tectonically interleaved garnet pyroxenites, calc-silicate rocks, quartzites and amphibole schists, decreasing in metamorphic grade structurally down from the overlying Lycian peridotite. Palaeotemperatures of $390-400^{\circ} \mathrm{C}$ for the structural top of the sole ( $<1 \mathrm{~m}$ from the peridotite contact) were calculated using garnet and pyroxene geothermometry (Ai 1994). This figure was obtained by analysing the composition of adjacent mineral cores and assuming pressures of 2 kbar (equivalent to $c .7 \mathrm{~km}$ ). This is a realistic figure for the thickness of the overlying ophiolite with a reconstructed crustal section. Consistently $50-80^{\circ} \mathrm{C}$ higher temperatures are produced by comparing data from adjacent garnet and pyroxene rims. Thus, the mineral rims preserve evidence of higher temperature equilibration than the cores. Therefore, a record of prograde metamorphism is preserved. Amphiboles within this metamorphic sole were dated by Thuizat et al. (1981), using K-Ar techniques, at c. $102 \mathrm{Ma}$.

\section{Supra-allochthon sediments}

Shallow-water limestones of Palaeogene age unconformably overlie the Lycian Allochthon (Fig. 2). At one locality,
Kozağacı (Fig. 1), there is a basal conglomerate dominated by cobbles of rounded serpentinite and volcanic rock in a red feldspar-rich arenite matrix (Fig. 10). These conglomerates are overlain by nodular wackestones which grade up into thicklybedded packestones containing Palaeocene benthic foraminfera (e.g. Miliolidae and small forms of Nummulites sp.; Collins 1997). Above are lithic-arenites including large (<20 m diameter) blocks of lithologies similar to the underlying limestone. Elsewhere (e.g. Inçeler; Fig. 1), the basal conglomerate is matrix supported and forms a wackestone with rounded pebbles of serpentinite and large benthic foraminifera (e.g. Nummulites sp.). These sediments pass up into medium to thickly bedded foraminiferal-wackestones containing wellpreserved bivalves and the planktonic foraminifera, Morozovella aragonensis (Collins 1997). The above microfauna dates the rocks as Lower to Middle Eocene. The youngest sediments within this conformable succession are dark marls packed with large ( $>1 \mathrm{~cm}$ diameter) Nummulites sp.

Throughout the Lycian Taurides, Neogene sediments are preserved in basins bounded by normal faults. The earliest evidence for this rift-related sedimentation in the Lycian Taurides is in the NE-SW-trending Tavas Basin (Fig. 1). Here, ophiolite-derived conglomerates occur along the basin margins and can be seen to interfinger with lacustrine and marginalmarine deposits in the centre of the basin. These deposits are dated as Upper Oligocene to Aquitanian by the presence of bivalves and gastropods, including Terebralia bidentata and Turritela gradata and rare horizons rich in benthic foraminifera such as Operculina ammonoides (Gökcen 1982; Hakyemez 1989). This evidence is important as it shows that extensional deformation within the hinterland of the Lycian Orogen was initiated whilst foreland-ward thrust-sheet translation was continuing at the front of the Lycian Allochthon.

\section{Kinematics of the boundaries between the tectonic units}

This section describes the kinematic relationship between individual tectonic units within the Lycian Orogen. The boundaries between the tectonic units are identified by locating surfaces, or zones, where a package of rock that shares a similar tectonic history is in contact with a package of rock with a differing tectonic history. These boundaries are either shear zones or regionally significant unconformities. In the case of the boundary being a shear zone, the actual geometry

Table 4. Selected XRF analyses of samples of dolerite that occur as dykes cutting peridotite within the Lycian Peridotite Thrust Sheet

\begin{tabular}{|c|c|c|c|c|c|c|c|c|c|c|c|c|c|}
\hline Sample & $\mathrm{Sr}$ & $\mathrm{K}_{2} \mathrm{O}$ & $\mathrm{Rb}$ & $\mathrm{Ba}$ & Th & $\mathrm{Nb}$ & $\mathrm{Ce}$ & $\mathrm{P}_{2} \mathrm{O}_{5}$ & $\mathrm{Zr}$ & $\mathrm{TiO}_{2}$ & $\mathrm{Y}$ & Sc & $\mathrm{Cr}$ \\
\hline $3 \mathrm{~S} 8 \mathrm{E}$ & 355.40 & 0.17 & 2.30 & 100.90 & 0.90 & 0.50 & 11.10 & 0.11 & 77.00 & 1.37 & 30.60 & 39.30 & 46.30 \\
\hline $3 \mathrm{~S} 32 \mathrm{~B}$ & 226.60 & 0.10 & 2.90 & 35.20 & 2.60 & 0.80 & 9.30 & 0.10 & 73.10 & 1.19 & 28.40 & 44.80 & 85.20 \\
\hline $3 \mathrm{~S} 7 \mathrm{~F}$ & 370.60 & 0.08 & 1.20 & 16.30 & 2.30 & 1.60 & 9.90 & 0.09 & 67.80 & 1.06 & 25.30 & 44.70 & 78.80 \\
\hline $3 \mathrm{~S} 7 \mathrm{G}$ & 396.60 & 0.12 & 1.10 & 30.40 & 1.40 & 0.90 & 14.20 & 0.09 & 66.90 & 1.06 & 24.90 & 45.10 & 89.00 \\
\hline $3 \mathrm{~S} 7 \mathrm{H}$ & 357.80 & 0.11 & 1.90 & 44.10 & 0.60 & 1.30 & 14.90 & 0.09 & 69.10 & 1.11 & 25.90 & 44.50 & 84.20 \\
\hline $3 \mathrm{~S} 31 \mathrm{C}$ & 40.10 & 0.16 & 3.10 & 20.90 & 3.50 & 1.50 & 14.20 & 0.16 & 118.40 & 2.03 & 43.90 & 42.30 & 45.50 \\
\hline 3S21K1 & 119.00 & 1.10 & 7.70 & 23.50 & 1.40 & 1.60 & 7.40 & 0.09 & 52.30 & 0.98 & 25.00 & 43.30 & 75.90 \\
\hline $3 \mathrm{~S} 21 \mathrm{I} 1$ & 652.20 & 0.26 & 5.80 & 256.40 & 1.20 & 1.50 & 8.40 & 0.06 & 67.80 & 0.73 & 26.30 & 40.00 & 64.40 \\
\hline $3 \mathrm{~S} 22 \mathrm{~J}$ & 570.80 & 0.26 & 3.30 & 128.10 & 1.50 & 1.90 & 9.20 & 0.09 & 62.60 & 1.07 & 25.30 & 36.90 & 56.90 \\
\hline $3 \mathrm{~S} 22 \mathrm{~K}$ & 396.60 & 0.25 & 1.80 & 108.40 & 0.20 & 1.10 & 6.80 & 0.05 & 55.60 & 0.95 & 22.40 & 42.20 & 79.40 \\
\hline $3 \mathrm{~S} 22 \mathrm{~K}(\mathrm{~A}$ & 387.00 & 0.00 & 2.30 & 103.80 & 0.30 & 1.40 & 9.00 & 0.00 & 54.50 & 0.00 & 24.00 & 42.10 & 77.50 \\
\hline
\end{tabular}




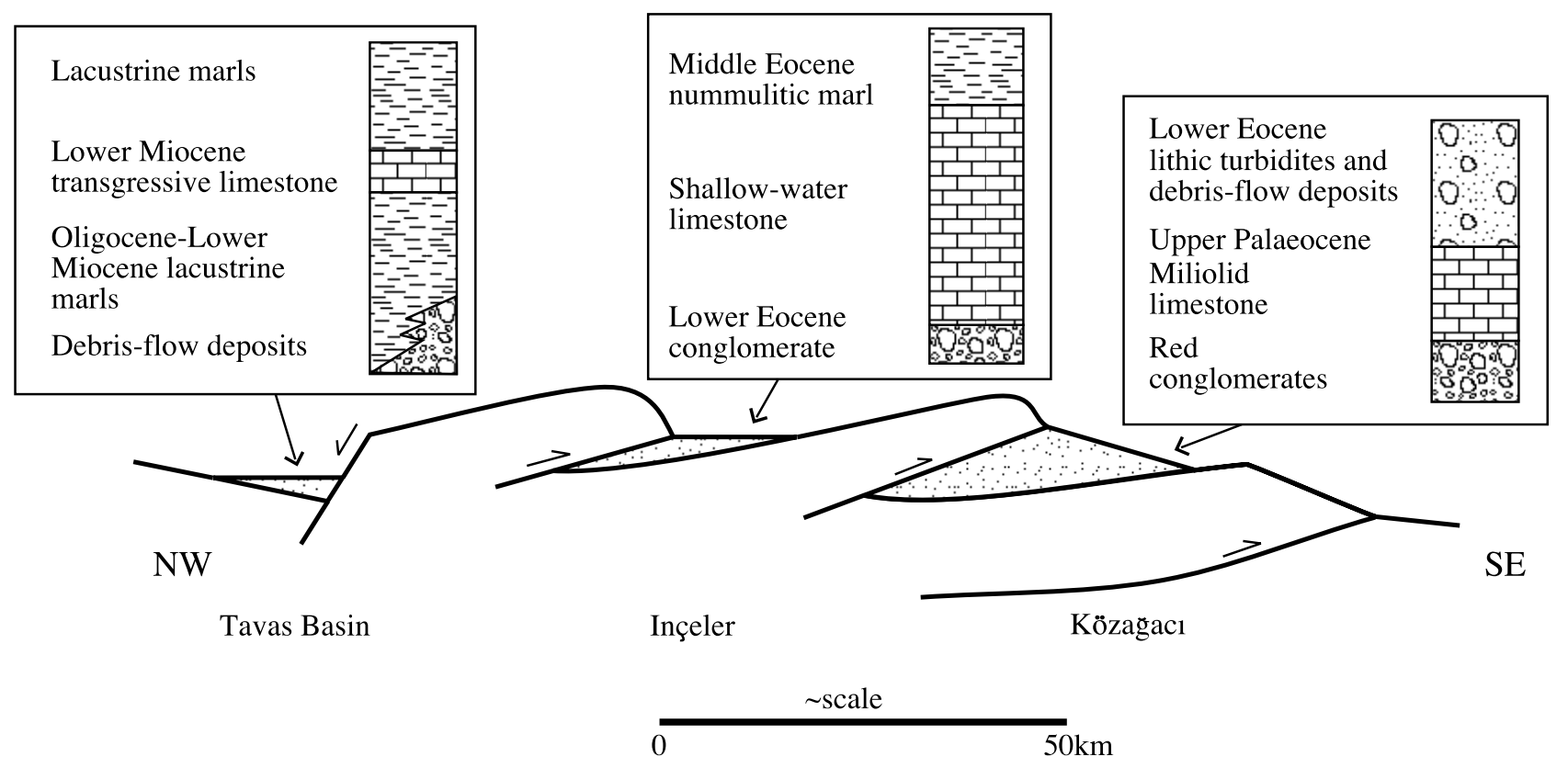

Fig. 10. Summary section through the Lycian Taurides indicating the tectonic position of supra-allochthon sedimentary successions. Palaeogene limestones, conglomerates and turbidites are imbricated into the thrust pile directly before Oligocene-Miocene extensional basin formation.

Table 5. Structural and kinematic relationship between tectonostratigraphic units involved in the Lycian Orogen

\begin{tabular}{lcc}
\hline $\begin{array}{l}\text { Contact between } \\
\text { tectonic units }\end{array}$ & $\begin{array}{c}\text { Contact between individual } \\
\text { thrust sheets }\end{array}$ & Kinematic relationship \\
\hline
\end{tabular}

Lycian Basement/

Lycian Thrust Sheets

Lycian Thrust Sheets/

Lycian Mélange

Lycian Mélange/

Lycian Peridotite Thrust Sheet

Lycian Peridotite Thrust Sheet/

Supra-allochthon sediments
Thrust contact top-to-SE shear

Yavus Thrust Sheet/ Teke Dere Thrust Sheet

Karadag Thrust Sheet/

Teke Dere Thrust Sheet

Teke Dere Thrust Sheet/

Köycegiz Thrust Sheet

Thrust contact not well exposed-deformation within the Yavus Thrust Sheet suggests top-to-SE shear

Thrust contact top-to-NW shear, transgressing

tectonostratigraphy

Thrust contact top-to-E or SE shear

Thrust contact top-to-SE shear

Thrust contact top-to-SE shear

Regional unconformity of the structure at the time it was active was not determined in the field. The identification of individual structures as grossly extensional or contractional features (with respect to palaeosurface) was not undertaken (cf. Wheeler \& Butler 1994; Ring 1995). Instead, kinematic evidence obtained from the shear zones (presented below) is coupled with sedimentological and geochemical evidence to infer overall tectonic evolution in the discussion section.

Kinematic evidence for the relationship between the tectonic units and the individual Lycian Thrust Sheets is summarized in Table 5. The Yavus Thrust Sheet is the lowermost Lycian Thrust Sheet in the frontal area. This unit shows considerable cataclastic deformation within $30 \mathrm{~m}$ of the basal thrust. Brittle shear fabrics (i.e. slickenside fabrics, thrust-horse geometry) record a top-to-the-southeast shear sense (Table 5). In more hinterland regions, the base of the Lycian Thrust Sheets is marked by a well developed carbonate ultra-mylonite with a mineral lineation defined by calcite crystals and stretched siliceous nodules. These siliceous nodules often show asymmetrical wings that define both $\sigma$-shaped and $\delta$-shaped fabrics in sections perpendicular to the fabric and parallel to the mineral elongation lineation (Passchier \& Trouw 1996). These features imply a top-to-the-east shear sense (Fig. 11a). Within the Lycian Thrust Sheets, the boundary between the Yavus Thrust Sheet and the overriding Teke Dere Thrust Sheet is cataclastically deformed, with rotated blocks and slickensided surfaces indicating top-to-the-southeast displacement. Eocene clastic sediments and volcanics of the uppermost Teke Dere Thrust Sheet have acted as a décollement horizon, with the overlying Köyceǧiz Thrust Sheet being translated southeastwards to eastwards relative to the Teke Dere Thrust Sheet. This has generated an intense shear foliation in the contact 

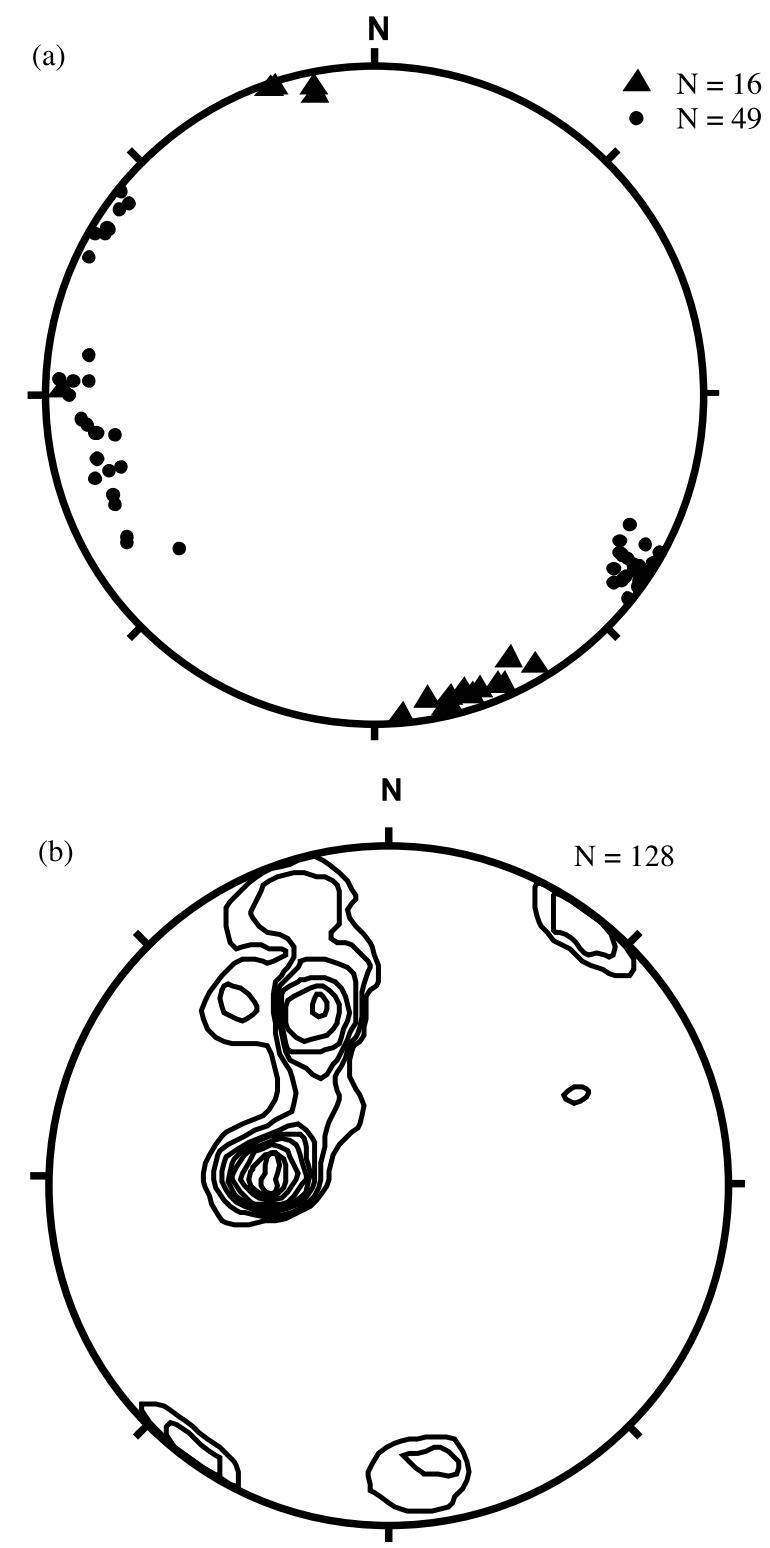

Fig. 11. (a) Equal-area lower hemisphere projection showing mineral elongation lineations from the base of the Lycian Allochthon, within $20 \mathrm{~m}$ of the Menderes Metamorphic Complex. Black circles are carbonate ultramylonites and cherty marbles from Arıldas (Fig. 1), black triangles are micritic marbles from the Nam Nam Çay valley (Fig. 1). Both localitites contain elements that imply top-to-the-southeast non-co-axial flow. (b) Mineral elongation lineations from amphibolite-grade rocks locally found directly beneath the Lycian Peridotite Thrust Sheet. Measurements are taken from highly strained rocks that contain elements that show general top-to-the-east/southeast non-co-axial flow. The readings come from exposures throughout the Lycian Allochthon (Fig. 1). Contours at $2.64 \%$ intervals with $21.09 \%$ in maximum contour. $N=128$.

zone with imbricated layers and $\mathrm{C} / \mathrm{S}$ fabric generation. The contact between the Teke Dere Thrust Sheet and the underlying Karadağ Thrust Sheet is only seen in the central part of the allochthon and displays a footwall ramp geometry, with the boundary thrust cutting through the stratigraphy of the Karadağ Thrust Sheet (i.e. the footwall), whilst remaining parallel to the stratigraphy of the Teke Dere Thrust Sheet (i.e. the hanging wall). This cross-cutting relationship and the stratigraphical similarities between the Karadağ Thrust Sheet and the Teke Dere Thrust Sheet, noted earlier, suggest that this contact is a late-stage back-thrust.

The Lycian Thrust Sheets are overthrust by the Lycian Mélange which is pervasively sheared. C/S-type fabrics, rotated blocks and fold asymmetries combine to imply a consistent top-to-the-south-east to top-to-the-east shear sense (Table 5). The overlying metamorphic sole of the Lycian Peridotite Thrust Sheet preserves a common mineral alignment developed by elongate amphibole crystals. These show a spread of orientations clustering in the NW quadrant (Fig. 11b), sheared boudins and intra-folial asymmetrical folds consistently show a general top-to-the-southeast sense of displacement. The supra-allochthon sediments unconformably overlie the allochthon, but locally they are imbricated by late-stage top-to-the southeast thrusts.

\section{Discussion}

Evidence for opening of Neotethys exists in the Lycian orogen but is largely out of the scope of this paper. By way of introduction, a brief summary is included here to place the subsequent events in perspective.

Carboniferous and Permian shallow-water limestones pass upwards into radiolarian cherts and Permian volcanic rocks in the Teke Dere Thrust Sheet (Graciansky 1972; Collins 1997). These are overlain by shallow-water limestones that pass up into slope facies by Mid-Triassic time. This has been interpreted as implying two-stages of rifting: one in Late Permian and one during Mid-Triassic time (Collins 1997). Rocks deposited from Mid-Triassic to Early Cretaceous times constitute a uniform succession of calc-turbidites and debrisflow deposits interpreted as representing the northern margin of the Menderes-Bey Dağları microcontinent.

Evidence for the closure of Neotethys is found within all of the tectonic units of Lycian Taurides. Kinematic relationships show that each of the thrust sheets originated to the west or northwest of their present position. The highest sediments of the litho-stratigraphy in each thrust sheet become progressively younger structurally downwards. This evidence supports an interpretation of the orogen as a forward-propagating thrust pile in which each newly incorporated thrust sheet originated from a position further southeastward than the previously detached thrust sheet. A palinspastic reconstruction can thus be achieved by restoring the uppermost thrust sheet to a position furthest northwest, whereas the lower thrust sheets are restored to locations successively closer to their present positions (Fig. 12). This reconstruction is necessarily qualitative (without line-length or volume balancing) in view of extensive post-Miocene extensional deformation that has affected the region and variability in transport direction from $\mathrm{NE}$ to $\mathrm{SE}$ as determined from kinematic evidence.

\section{Cretaceous: initiation of intra-oceanic subduction, trench/passive margin collision and ophiolite obduction}

Oceanic lithosphere that existed within the root zone of the Lycian Allochthon, to the north of the Menderes Metamorphic Complex, formed prior to $102 \mathrm{Ma}$. (i.e. Early Cretaceous). This is the age of syn-deformational metamorphism of the amphibolite sole of the Lycian Peridotite Thrust Sheet (Thuizat et al. 1981). Whitechurch et al. (1984) suggested that these metamorphic rocks originated as uppermost oceanic crust that was metamorphosed and welded onto 
N

(a)

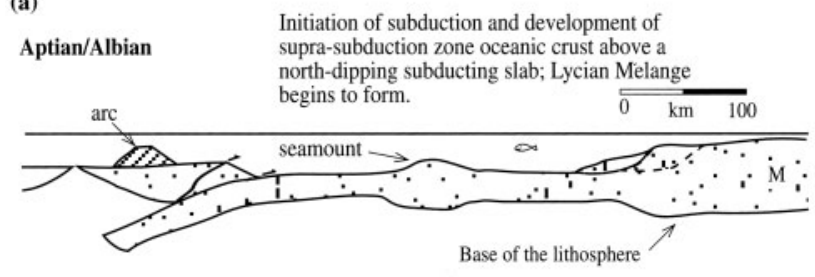

Closure of ocean with continent/continent

(c) Middle Eocene

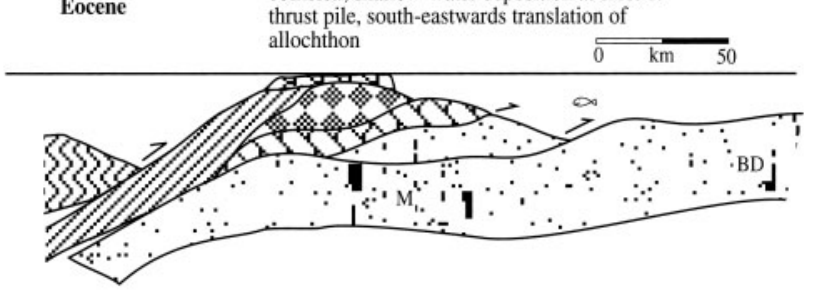

(b)

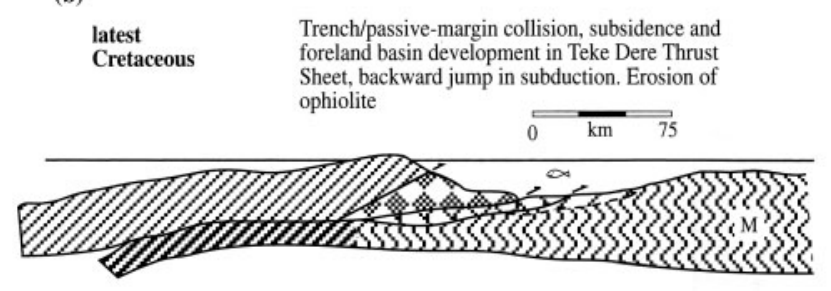

(d)
S

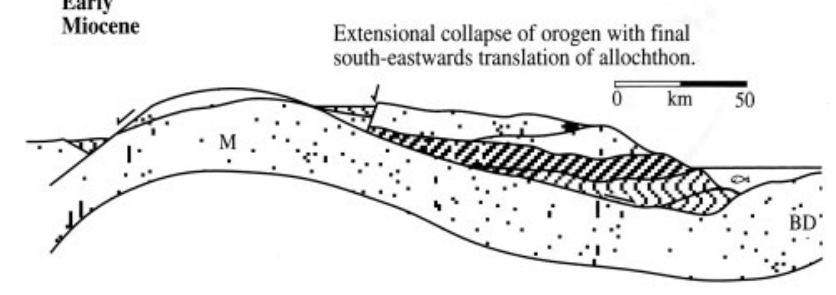

Fluvial \& lacustrine sediments
Yithoclastic sediments of the
Favuz Thrust Sheet
Lithologies now incorporated within
the Teke Dere Thrust Sheet
Kithologies now incorporated within the
Koycegiz Thrust Sheet

\author{
Supra-subduction zone oceanic crust of the \\ The Lycian Melange \\ C.d Continental para-autochthonous crust \\ Lycian Peridotite Thrust Sheet \\ Oceanic crust, now subducted \\ M Site of present Menderes Metamorphic Complex \\ BD Site of present Bey Daglan
}

Fig. 12. Tectonic reconstructions for formation of the Lycian Taurides from the Cretaceous to the Miocene.

the base of a hot overthrusting slab of oceanic crust during the initial stages of intra-oceanic subduction. Above the sole rocks, the serpentinized peridotite is interpreted as representing the lower levels of an ophiolite succession; i.e. sub-oceanic mantle lithosphere. Crustal rocks are not preserved within the Lycian Peridotite Thrust Sheet. A mantle transition zone marking the petrological Moho (Boudier \& Nicolas 1995) has not been observed. We assume that the Lycian Peridotite Thrust Sheet was originally a complete ophiolite that was deeply eroded after genesis at a spreading centre (probably after obduction), consistent with its present structurally high position within the orogen.

The ultramafic rocks of the Lycian Peridotite Thrust Sheet are geochemically distinct from counterparts formed at midocean-ridge (MOR) spreading centres in the modern oceans (Dick \& Bullen 1984). Whole-rock and chrome-spinel traceelement compositions are depleted in incompatible elements relative to peridotites from modern MOR settings (Figs 7 \& 8). These factors suggest that considerably larger degrees of partial melting took place to form the Lycian peridotite than in average sub-oceanic mantle lithosphere. Pearce et al. (1984) suggested that similarly depleted peridotites from Oman and the eastern Mediterranean region (e.g. Troodos, Cyprus) represent oceanic lithosphere that experienced a second phase of partial-melt extraction under hydrous conditions, with a fluid component introduced from a subducted slab of oceanic crust. Such a supra-subduction tectonic setting for the origin of the Lycian Peridotite Thrust Sheet is also consistent with the observed trace-element concentrations in late-stage dolerite dykes (e.g. depletion in Nb; Fig. 9) that intruded the peridotite prior to obduction. These dykes are interpreted to be the roots of an arc system that has been eroded with the rest of the crustal section of the ophiolite. The extensive lithic arenites found within Tertiary successions of the Lycian Thrust Sheets and the present-day foreland basin (i.e. the Kaş basin; Fig. 1) are thought to be the erosion products of the crustal section of the ophiolite.

The Ophiolitic Mélange also formed during the earlier stages of convergence (Collins \& Robertson 1997). Basaltic inclusions in the mélange are likely to have erupted at both oceanic ridge (i.e. MOR/SSZ basalts) and oceanic seamount settings (i.e. within-plate basalts). Inclusions of sedimentary rocks, within the mélange, were originally deposited in both pelagic, deep marine/oceanic (i.e. pelagic limestone, radiolarian-rich chert and black chert), and shallow-marine environments (i.e. neritic limestone). The mélange matrix consists of sediments derived from both igneous and deep-sea sedimentary sources. The compositions of clasts within conglomeratic parts of the matrix (e.g. serpentinite and radiolarian-rich chert) suggest the Lycian Peridotite Thrust Sheet as the probable source. The age of these lithologies in the mélange range from Triassic to Late Cretaceous (Graciansky 1972; Poisson 1977), implying that the unit was not completely amalgamated until the Late Cretaceous (Collins \& Robertson 1997). Similarities of included lithologies, deformation style and degree of metamorphism between the Lycian Ophiolitic Mélange and modern oceanic subduction/accretionary complexes (e.g. Barbados, Mascle \& Moore 1990) led Collins \& Robertson (1997) to propose that the Lycian Ophiolitic Mélange formed as an intra-oceanic subduction/accretionary complex. Mélanges of inferred subduction/accretion origin, akin to the Ophiolitic Mélange occur in association with ophiolites in many other 
areas, including the Pindos Mountains, northwest Greece (Jones \& Robertson 1991), Oman (Searle \& Graham 1982), west North America (Byrne 1984; Cowan 1985), Himalayas (Reuber et al. 1987).

The Layered Tectonic Mélange (see Fig. 2) consists exclusively of highly deformed sedimentary rocks that were deposited in the same sedimentary environment; i.e. a relatively deep, quiet, passive oceanic, environment. This mélange tectonically overrides an imbricated passive-margin succession (the Lycian Thrust Sheets) and is overridden by a subduction/ accretion complex (the Ophiolitic Mélange). The Layered Tectonic Mélange is thus interpreted as deposited in a distal passive-margin setting. No reliable dates have been obtained from this unit, but because of its structural position it is interpreted to be a condensed corollary of the Mesozoic succession within the Lycian Thrust Sheets.

The root zone of the Lycian Thrust Sheets was tectonically stable throughout much of the Mesozoic. Sediments within the thrust sheets are interpreted to have been deposited on a continental slope as part of a Neotethyan passive margin. The first marked sedimentary change occurred in the Turonian, with an abrupt incoming of lithic arenites within the Köyceğiz Thrust Sheet. These arenites include volcanogenic grains interpreted to have been derived from the upper levels of an ophiolite, probably the Lycian Peridotite Thrust Sheet. These sediments are similar to those found in Miocene foreland basin deposits within the uppermost levels of the Bey Dağları Unit (i.e. the Kaş Basin, Hayward 1984, Fig. 1). The Miocene foreland basin sediments were derived from the Lycian Allochthon (Hayward 1984) and the Turonian lithic arenites within the Köyceğiz Thrust Sheet are interpreted to have a similar provenance. These arenites provide the earliest evidence of hanging-wall-derived sediments within the Lycian Thrust Sheets and, as such, can be used to estimate the possible length of the slab consumed during Late Cretaceous subduction under the Lycian Peridotite Thrust Sheet. A period of 12-14 Ma (Harland et al. 1990 timescale) elapsed between initiation of intra-oceanic subduction (i.e. the date of cooling of the ophiolitic sole) in an oceanic basin to the north of the root zone of the Köyceğiz Thrust Sheet and the first evidence of proximity of this thrust sheet to the continental margin. At a conservative subduction rate $\left(4 \mathrm{~cm} \mathrm{a}^{-1}\right)$, between 480 and $560 \mathrm{~km}$ of oceanic crust were consumed. However, sedimentation within the Köyceğiz Thrust Sheet did not end until the Maastrichtian, a minimum of $14.5 \mathrm{Ma}$ later. Therefore, at a realistic, constant, post-collisional, convergence rate of $2 \mathrm{~cm}$ $\mathrm{a}^{-1}$, another $290 \mathrm{~km}$ of shortening occurred prior to overthrusting of the Lycian Peridotite Thrust Sheet over the Köyceğiz Thrust Sheet.

The Teke Dere Thrust Sheet shows no evidence for the proximity of an ophiolite until the end of the Cretaceous. Therefore, the Teke Dere Thrust Sheet originated further from the passive margin of the ocean basin than the Köyceğiz Thrust Sheet. Likewise, the southern margin of the Menderes Metamorphic Massif preserves carbonate sedimentation to the end of the Cretaceous, suggesting a similar, more inboard, origin.

\section{Palaeocene-Eocene: tectonic stabilization; erosion, marine transgression then continent-continent collision}

Palaeocene and Eocene sediments associated with both the autochthonous and allochthonous units show evidence of an extended period of tectonic quiescence. The Palaeocene succes- sion near the southern margin of the Menderes Metamorphic Complex is characterized by pelagic carbonate rocks. The allochthonous Teke Dere Thrust Sheet shows evidence of pelagic sediments being superseded by ophiolite-derived turbidites and debris-flow deposits in the Middle Eocene. These sedimentary rocks are intercalated with basaltic volcanics within $<20 \mathrm{~m}$ of the thrust contact with the overriding Köyceğiz Thrust Sheet. The chemical composition (see earlier) and situation within debris-flow deposits implies that these volcanic rocks erupted in an extensional setting. The proximity of the Köyceğiz Thrust Sheet suggests that the volcanics erupted shortly before being overridden by this large thrust sheet. Thus, Eocene volcanic rocks within the Teke Dere Thrust Sheet are interpreted to have erupted in a foreland basin. The timing of overriding of the Köyceğiz Thrust Sheet above the Teke Dere Thrust Sheet is coeval with detachment of the latter and its incorporation into the allochthon in Mid-Late Eocene times.

The upper levels of the Lycian Allochthon were subaerially exposed for some time between the latest Cretaceous and the Late Palaeocene, during which a red stained conglomerate was deposited above the Lycian Mélange. Sediments derived from the eroding ophiolite were deposited in foreland basins, now found within the Teke Dere Thrust Sheet and Menderes Metamorphic Complex. Late Palaeocene-Early Eocene transgressive marine limestones overlie the conglomerate. These sedimentary rocks are themselves overlain by Mid-Eocene lithic arenites and debris-flow deposits deposited during a renewed phase of thrust sheet translation.

The Yavus Thrust Sheet is interpreted as Lower Eocene to Lower Oligocene (Poisson 1977) foreland basin sediments, mainly derived from basic volcanic rocks within the Lycian Allochthon. The relatively young age of these sediments is probably because the Yavus Thrust Sheet originated forelandward of both the Menderes Metamorphic Massif and the Teke Dere Thrust Sheet (Fig. 12). These lithologies and age relationships suggest that thrust sheet motion occurred from Mid-Late Eocene to Early Oligocene times.

The autochthonous Bey Dağları Unit lies forelandward of the root-zone of all of the Lycian Thrust Sheets. During deposition, hiatuses occurred in the Late Cretaceous and the Early Miocene (Poisson 1977). Also, within the Eocene succession a debris-flow deposit is locally found (Gutnic et al. 1979). This deposit contains boulders of chert, shallow-water limestone and serpentinite. The concurrence of these events with periods of thrust sheet translation suggests that they represent base-level changes foreland-ward of the orogen.

The Mid-Eocene to Early Oligocene period of thrust-sheet translation was roughly contemporaneous with shear-zone development in the Menderes Metamorphic Complex (Hetzel \& Reischmann 1996). It involved incorporation of extensive thrust sheets into the orogen (i.e. the Teke Dere and Yavus Thrust Sheets) and was coeval with Eocene maximum metamorphism within the Menderes Metamorphic Complex (Şengör et al. 1984; Satır \& Friedrichsen 1986), both suggestive of crustal thickening. Shear zones dated by Hetzel \& Reischmann (1996) show no transition from ductile to brittle deformation across them (an observation noted by Hetzel \& Reischmann) and no resolvable jump in metamorphic grade between hanging-wall and foot-wall rocks. This suggests that rocks from similar crustal levels are juxtaposed against each other, implying that little or no exhumation was facilitated by these shear zones. This evidence combined with the tectonostratigraphic evidence from the Lycian Allochthon and the Bey 
Dağları Unit, suggests that the 43-37 Ma muscovite $\mathrm{Ar}-\mathrm{Ar}$ ages of Hetzel \& Reischmann (1996) date cooling of the Menderes Metamorphic Complex after a period of contractional, rather than extensional, deformation. The cause of this cooling was probably due to erosion of the Lycian Peridotite Thrust Sheet.

What caused the Early Tertiary thrusting? After initial emplacement of the Lycian Peridotite Thrust Sheet in the latest Cretaceous, an oceanic basin is inferred to have remained to the north of the Menderes Metamorphic Complex (see Fig. 12). Renewed convergence between Africa and Europe in the Palaeogene (Dewey et al. 1989) instigated consumption of this relict oceanic crust along a northerly subduction (evidence within the Ankara-Izmir suture zone; Fig. 1; Erdoğan \& Güngör 1992; our unpublished data). This culminated in continent-continent collision after all remaining oceanic crust had been subducted by Late Eocene times.

\section{Oligocene-Miocene: southeastwards thrust-sheet translation coeval with rifting in the hinterland}

Sedimentary successions within the area of the Göcek Windows, where the Bey Dağları Unit is exposed within a tectonic culmination (Fig. 1), show that sub-aerial exposure took place during Late Oligocene time, whereas overlying Aquitanian limestones mark a return to shallow-marine conditions, prior to an influx of ophiolite-derived clastic sediments in the Burdigalian. By contrast, the first appearance of ophiolite-derived sedimentary rocks did not occur until Langhian times in the Bey Dağları Unit, to the east, and syn-deformational sediments persisted until Tortonian times. This diachronity led Hayward (1984) to infer that southeastwards thrusting of the Lycian Allochthon over the Bey Dağları Unit took place at a rate of $c .2 .5 \mathrm{~cm} \mathrm{a}^{-1}$

During the Miocene phase of thrust-sheet translation, extensional deformation began within the hinterland (Fig. 10). In the Tavas Basin, to the northwest (Fig. 1), rift-related sediments were deposited in latest Oligocene/earliest Miocene times. Sediments were initially ophiolite-derived fluvial deposits interfingering with lacustrine marls in the centre of the basin. Localized deformation of the eastern basin margin is marked by an angular unconformity at the base of the Aquitanian. More general rifting was initiated throughout the Menderes Metamorphic Complex during Late Oligocene to Early Miocene times (Seyitoğolu et al. 1992; Purvis \& Robertson 1997).

Coeval thrust-sheet translation in foreland regions and extensional basin formation in hinterland regions of the Lycian Orogen is here interpreted as the result of latest OligoceneMiocene extensional collapse by gravitational spreading (e.g. Dewey 1988; Malavieille 1993). During this deformation phase, the thrust pile was simply translated along a basal shear zone, without accretion of any additional thrust sheets. The base of the Lycian allochthon is envisaged as an extensional detachment zone that reactivated a contractional shear zone.

This interpretation for the evolution of the Lycian Taurides provides an explanation of the present distribution of lithologies and structures seen throughout the region. In comparison, previous interpretations (Table 1) were based upon restricted field areas and failed to explain the overall orogenic evolution. Integrating sedimentological and structural analysis with geochemical and palaeontological data provide the only way to attempt a comprehensive understanding of complex orogenic regions such as the Lycian Taurides.

\section{Conclusions}

The Lycian Allochthon was amalgamated during three main events: (1) latest Cretaceous trench-passive margin collision causing ophiolite obduction and incorporation of the Köyceğiz Thrust Sheet into the Lycian allochthon; (2) Middle-Late Eocene continent-continent collision causing renewed southeastwards thrusting and incorporation of the Teke Dere Thrust sheet and the Yavus Thrust Sheet into the Lycian allochthon; (3) Miocene extensional collapse causing southeastwards translation of the assembled thrust pile.

There are a number of important conclusions that come from this study. The most important is the need for full integration of structural and sedimentological field work with geochemical and palaeontological analyses to work out the tectonic evolution of a structurally complex area. The Lycian Taurides exemplifies how the present outcrop is determined by a combination of processes, including subduction, obduction, continental collision and extensional collapse. The importance of subduction-accretion was previously unrecognized in the area and is shown to be an important process in developing one of the most volumetrically important rock units (i.e. the Lycian Mélange).

Structurally, the basal detachment of the Lycian Allochthon formed as a thrust during early contractional deformation and was reactivated during Oligocene-Miocene extensional collapse. This inheritance of early structures, that formed within a different stress regime, is a commonly recognized feature of inverted sedimentary basins (e.g. Butler 1992). The opposite case where extensional faults reactivate thrusts has been documented from other orogenic belts (e.g. the Caledonides; Coward et al. 1989). However, rather than being reactivated with an opposite sense-of-movement, as is the case in the Scottish Caledonides, the fault at the base of the Lycian Allochthon was episodically reactivated with a constant kinematic sense (i.e. to the east).

A.S.C. would like to thank NERC who funded this work as part of his $\mathrm{PhD}$ project based at the Dept. of Geology and Geophysics, Edinburgh University. A.S.C. would also like to thank the Geological Society of London as trustees of the Fermor Fellowship and Leicester University for providing finance and facilities to write this paper. A.H.F.R. would like to thank Edinburgh University for providing a financial contribution to fieldwork. Both authors are indebted to T., A. and E. Ustaömer for their friendship and logistical support. Constructive reviews by G. Oliver and U. Ring considerably improved this manuscript.

\section{References}

AI, Y. 1994. A revision of the garnet-clinopyroxene $\mathrm{Fe}^{2+}-\mathrm{Mg}$ exchange geothermometer. Contributions to Mineralogy and Petrology, 115, 4, 465-473.

Boudier, F. \& Nicolas, A. 1995. Nature of the Moho Transition Zone in the Oman Ophiolite. Journal of Petrology, 36, 777-796.

ButLer, R.W.H. 1992. Structural development at the Pennine Front, Rocher d'L'Yret, Western Alps. Journal of Structural Geology, 14, 29-40.

BYrnE, T. 1984. Early deformation in melange terranes of the Ghost Rocks Formation, Kodiak Islands, Alaska. In: Raymond, C.A. (ed.) Melanges: Their nature, origin and significance. Geological Society of America, Special Papers, 198, 21-51.

Collins, A.S. 1997. Tectonic evolution of Tethys in the Lycian Taurides, southwest Anatolia. $\mathrm{PhD}$ thesis, University of Edinburgh.

_ \& Robertson, A.H.F. 1995. Modes of late Mesozoic to mid Tertiary contractional tectonics in south Tethys; evidence from the Lycian nappes, SW Turkey. Terra abstracts, 7, 176.

_ \& 1997. Lycian melange, southwestern Turkey: An emplaced Late Cretaceous accretionary complex. Geology, 25, 255-258. 
Cowan, D.S. 1985. Structural styles in Mesozoic and Cenozoic mélanges in the western Cordillera of North America. Geological Society of America Bulletin, 96, 451-462.

Coward, M.P., Enfield, M.A. \& Fischer, M.W. 1989. Devonian basins of northern Scotland: extension and inversion related to late CaledonianVariscan tectonics. In: CoOper, M.A. \& Williams, G.D. (eds) Inversion Tectonics. Geological Society, London, Special Publications, 44, 275-308.

Dewey, J.F. 1988. Extensional collapse of orogens. Tectonics, 7, 1123-1139.

—, Helman, M.L., Turco, E., Hutton, D.H.W. \& Knott, S.D. 1989. Kinematics of the western Mediterranean. In: CowARD, M.P., DiETrich, D. \& PArk, R.G. (eds) Alpine Tectonics. Geological Society, London, Special Publications, 45, 265-283.

Dick, H.J.B. \& Bullen, T. 1984. Chromium spinel as a petrogenetic indicator in abyssal and alpine-type peridotites and spatially associated lavas. Contributions to Mineralogy and Petrology, 86, 54-76.

Dora, O.O., Candan, O., Dürr, S. \& Oberhansli, R. 1995. New evidence concerning the evolution of the Menderes Massif. International Earth Sciences Colloquium on the Aegean Region, program \& abstracts, 13.

DÜRR, S. 1975. Über Alter und geotektonische Stellung des Menderes-Kristallins, $S W$-Anatolien, und seine Aquivalente in der mittleren Ägäis. Habilitationsschrift, Marburg/Lahn.

—, Altherr, R., Keller, J., Okrusch, M. \& Seidel, E. 1978. The Median Aegean Crystalline Belt: Stratigraphy, structure, metamorphism, magmatism. In: Cloos, H., Roeder, D. \& Schmidt, K. (eds) Alps, Apennines, Hellenides. Schweizerbart'sche Verlagsbuchhandlung, Stuttgart, 455-477.

Engin, T. \& Hirst, D.M. 1970. The Alpine chrome ores of the AndizlikZimparalik area, Fethiye, SW Turkey. Mineralogical Magazine, 38, 76-82.

ERDoĞAN, B. \& GÜNGÖR, T. 1992. Stratigraphy and tectonic evolution of the northern part of the Menderes massif. Turkish Association of Petroleum Geologists Bulletin (Ankara), c.4.1, 9-34.

Ersoy, S. 1990. Batı Toros (Likya) naplarının yapırsal oğerlerinin ve evriminin analizi. Jeoloji Muhendisliği, 37, 5-16.

1997. The syn-collisional deep-water sediments of the Marmaris complex as part of the Lycian Nappes, the SW Türkiye. In: PIșkin, O., ErGüN, M., Avaşçin, M.Y. \& Tarcan, G. (eds) Proceedings of the International Earth Sciences Colloquim on the Aegean Region, 9-14 Oct. 1995, Izmir/Güllük. 95-11.

FARINACCI, A. \& KöYlüOĞLU, M. 1982. Evolution of the Jurassic-Cretaceous Taurus shelf (southern Turkey). Bollettino della Società Paleontologica Italiana, 21, 267-276.

GöKCEN, N. 1982. Denizli ve Mugla cevresi neojen istifinin ostrakod biyostratigrafisi. (The ostracod biostatigraphy of the Denizli Mugla Neogene sequence). Yerbilimleri, 8, 111-133.

Graciansky, P.C. DE 1967. Existance d'une nappe ophiolitique à l'extrémité occidentale de la chaîne sud-anatolienne; relations avec les autre unités charriées et al. avec terrains autochtones (Province de Muğla, Turquie). Comptes Rendus de l'Academie des Sciences, Paris, 264, 2876-2879.

— 1972. Recherches geologiques dans le Taurus Lycien Occidental, DSc thèsis; Universite de Paris-sud, Centre d'Orsay.

Gutnic, M., Monod, O., Poisson, A. \& Dumont, J.-F. 1979. Géologie des Taurides Occidentales (Turquie). Mémoires de la Société Géologique de France, 137, 1-112.

Hakyemez, H.Y. 1989. Geology and stratigraphy of the Cainozoic sedimentary rocks in the Kale-Kurbalik area, Denizli, Southwestern Turkey. Bulletin of Mineral Resources Exploration (Turkey), 109, 1-14.

Harland, W.B., Armstrong, R.C., Cox, A.V., Craig, L.E., Smith, A.G. \& Smith, D.G. 1990. A geological timescale 1989. Cambridge University Press, Cambridge.

Hayward, A.B. 1984. Miocene clastic sedimentation related to the emplacement of the Lycian Nappes and the Antalya Complex, SW Turkey. In: Dixon, J.E. \& Robertson, A.H.F. (eds) The Geological Evolution of the Eastern Mediterranean. Geological Society, London, Special Publications, 17, 287 301.

Hetzel, R. 1995. The Alpine tectono-metamorphic evolution of the central Menderes Massif, southwestern Turkey. Doktor der Naturwissenschaften Dissertation. Mainz.

— \& ReIschmanN, T. 1996. Intrusion age of Pan-African augen gneisses in the southern Menderes Massif and the age of cooling after Alpine ductile extensional deformation. Geological Magazine, 133, 565-572.

-, Ring, U., Akal, C. \& Troesch, M. 1995. Miocene NNE-directed extensional unroofing in the Menderes Massif southwestern Turkey. Journal of the Geological Society, London, 152, 639-654.

Jones, G. \& Robertson, A.H.F. 1991. Tectonostratigraphy and evolution of the Mesozoic Pindos ophiolite and related units, northwestern Greece. Journal of the Geological Society, London, 148, 267-288.
KAADEN, G. VAN DER 1959. On the relationship between the composition of chromites and their tectonic-magmatic position in peridotite bodies in the SW of Turkey. Bulletin Maden ve Tetkik Arama Enstitüsü (Ankara), 52, $1-14$.

Khan, M.A., Stern, R.J., Gribble, R.F. \& Windley, B.F. 1997. Geochemical constraints on subduction polarity, magma sources, and palaeogeography of the Kohistan intra-oceanic arc, northern Pakistan Himalaya. Journal of the Geological Society, London, 154, 935-946.

Konak, N., Akdeniz, N., Öztürk, E.N. \& Doyuran, S. 1987. Geology of the south Menderes Massif. In: IGCP Project 5: Guide book for a field excursion in Western Anatolia, Turkey. Mineral Resourses Exploration Institute of Turkey, Ankara.

KRÖNER, A. \& SengöR, A.M.C. 1990. Archean and Proterozoic ancestry in lower Pre-Cambrian to early Palaeozoic crustal elements of southern Turkey as revealed by single zircon dating. Geology, 18, 1186-1190.

Malavieille, J. 1993. Late orogenic extension in mountain belts: Insights from the Basin and Range and the Late Palaeozoic Variscan belt. Tectonics, 12, 1115-1130.

Mascle, A. \& Moore, J.C. 1990. ODP Leg 110: Tectonic and hydrologic synthesis. In: Moore, J.C. \& Mascle, A. et al. (eds) Proceedings of the Ocean Drilling Program, Scientific results, 110. Ocean Drilling Program, College Station, Texas, 409-422.

OKAY, A. 1989. Geology of the Menderes Massif and the Lycien Nappes south of Denizli, western Taurides. Mineral Research Exploration Bulletin (Ankara), 109, 37-51.

ÖZKAYA, I. 1990. Origin of the allochthons in the Lycian belt southwest Turkey. Tectonophysics, 177, 367-379.

— 1991. Evolution of a Tertiary volcanogenic trough in S.W. Turkey-The Alakaya Basins of the Lycien Belt. Geologische Rundschau, 80, 657-668.

Passchier, C.W. \& Trouw, R.A.J. 1996. Microtectonics. Springer, Berlin.

PeArCE, J.A. 1983. Role of the sub-continental lithosphere in magma genesis at active continental margins. In: Hawkesworth, C.J. \& Norry, M.J. (eds) Continental basalts and mantle xenoliths. Shiva, Nantwich, 230-249.

— \& Norry, M.J. 1979. Petrogenic implications of Ti, Zr, Y and $\mathrm{Nb}$ variations in volcanic rocks. Contributions to Mineralogy and Petrology, 69, 33-47.

- Lippard, S.J. \& Roberts, S. 1984. Characteristics and tectonic significance of supra-subduction zone ophiolites. In: KokelaAR, B.P. \& Howells, M.F. (eds) Marginal Basin Geology. Geological Society, London, Special Publications, 16, 77-94.

Pickett, E.A. \& Robertson, A.H.F. 1996. Formation of the Late PalaeozoicEarly Mesozoic Karakaya Complex and related ophiolites in NW Turkey by Palaeotethyan subduction-accretion. Journal of the Geological Society of London, 153, 995-1009.

Poisson, A. 1977. Recherches géologiques dans les Taurides occidentales (Turquie), DSc thèsis. Universitie de Paris-Sud, Orsay.

Purvis, M.G.M. \& Robertson, A.H.F. 1997. Multiphase rifting in rapidly extending continental crust (West Turkey). Terra Nova, abstracts supplement, 9, 398.

Reuber, I., Colchen, M. \& Mevel, C. 1987. The geodynamic evolution of the South Tethyan margin in Zanskar, NW Himalaya. as revealed by the Spontang ophiolitic melanges. Geodynamica Acta (Paris), 1, 283-296.

RING, U. 1995. Horizontal contraction or horizontal extension? Heterogeneous Late Eocene and Early Oligocene general shearing during blueschist and greenschist facies metamorphism at the Pennine-Austroalpine boundary zone in the Western Alps. Geologische Rundschau, 84, 843-859.

Robertson, A.H.F. 1994. Tectonic Facies Concept and its application to Tethys in the Eastern Mediterranean region. Earth and Planetary Reviews, 37, $139-213$.

— \& Degnan P.J. 1993. Sedimentology and tectonic implcations of the Lamayuru Complex: deep-water facies of the Indian passive margin. In: Treloar, P.J. \& Searle M.P. (eds) Himalayan Tectonics. Geological Society, London, Special Publications, 74, 299-322.

- Dixon, J.E., Brown, S., Collins, A., Morris, A., Pickett, E., Sharp, I. \& Ustaömer, T. 1996. Alternative tectonic models for the Late PalaeozoicEarly Tertiary development of Tethys in the Eastern Mediterranean region. In: Morris A. \& TARLIng, D.H. (eds) Palaeomagnetism and Tectonics of the Mediterranean Region. Geological Society, London, Special Publications, 105, 239-263.

SAtr, M. \& FriedrichSen, H. 1986. The origin and evolution of the Menderes Massif, W-Turkey: A rubidium/strontium and oxygen isotope study. Geologische Rundschau, 75, 703-714.

Searle, M.P. \& Graham, G.M. 1982. 'Oman Exotics'-oceanic carbonate build-ups associated with the early stages of continental rifting. Geology, 10, 43-49. 
—, Windley, B.F., Coward, M.P., Cooper, D.W.J., ReX, A.J., Li Tingdong, D.C., Xuchang, X., Jan, M.Q., Thakur, V.C. \& Kumar, S. 1987. The closing of Tethys and tectonics of the Himalayas. Geological Society of America Bulletin, 98, 678-701.

- Corfield, R.L., Stephenson, B. \& McCarron, J. 1997. Structure of the North Indian continental margin in the Ladakh-Zanskar Himalayas: Implications for the timing of obduction of the Spontang ophiolite, India-Asia collision and deformation events in the Himalaya. Geological Magazine, 134, 297-316.

SENEL, Y.M. 1991. Palaeocene-Eocene sediments interbedded with volcanics within the Lycian Nappes: Faralya Formation. Bulletin of Mineral Research and Exploration (Turkey), 113, 1-14.

- Selçuk, H., Bilgin, Z.R., Sen, A.M., Karaman, T., Dinçer, M.A., Durukan, E., Arbas, A., ÖrÇan, S. \& Bilgi, C. 1989. Cameli (Denizli)—Yeşilova (Burdur)—Elmalı (Antalya) ve Doloyının Jeolojisi. Maden Tetkik ve Arama Genel Müdürlüğü Jeoloji Etüdleri Dairesi (Ankara)—Report 9429.

SEngör, A.M.C. \& Dewey, J.F. 1990. Terranology: vice or virtue. Philosophical Transactions of the Royal Society of London, A331, 457-467.

—_, SATiR, M. \& Аккӧк, R. 1984. Timing of tectonic events in the Menderes Massif, Western Turkey: Implications for tectonic evolution and evidence from Pan-African basement in Turkey. Tectonics, 3, 693-707.

SeyitoĞolu, G., Scott, B. \& Rundle, C.C. 1992. Timing of Cenozoic extensional tectonics in west Turkey. Journal of the Geological Society, London, 149, 533-538.
Smith, A.G., Hynes, A.J., Menzies, M., Nisbet, E.G., Price, I., Welland, M.J.P. \& FERrière, J. 1975. The stratigraphy of the Othris mountains, eastern central Greece: a deformed Mesozoic continental margin sequence. Eclogae Geologicae Helvetinae, 68, 463-481.

Thuizat, R., Whitechurch, H., Montigny, R. \& Juteau, T. 1981. K-Ar dating of some intra-ophiolite metamorphic soles from the East Mediterranean: New evidence for oceanic thrusting before obduction. Earth and Planetary Science Letters, 52, 302-310.

Ustaömer, T. \& Robertson, A.H.F. 1994. Late Palaeozoic marginal basin and subduction-accretion: The Palaeotethyan Küre Complex, Central Pontides, northern Turkey. Journal of the Geological Society, London, 151, 291305.

Vedder, J.G., Howell, D.G. \& McLean, H. 1985. Stratigraphy, sedimentation and tectonic accretion of exotic terranes, Southern Coastal Ranges, California. In: Howell, D.G. (ed) Tectonostratigraphic Terranes of the Circum-Pacific. Circum-Pacific Council for Energy and Resources, Houston, Texas, 471-479.

WheELER, J. \& ButLer, R.W.H. 1994. Crieria for identifying structures related to true crustal extension in orogens. Journal of Structural Geology, 16, 1023-1027.

Whitechurch, H., Juteau, T. \& Montigny, R. 1984. Role of the Eastern Mediterranean ophiolites (Turkey, Syria, Cyprus) in the history of the Neo-Tethys. In: Dixon, J.E. \& RoberTson A.H.F. (eds) The Geological Evolution of the Eastern Mediterranean. Geological Society, London, Special Publications, 17, 301-318.

Received 22 December 1997; revised typescript accepted 9 February 1998.

Scientific editing by Rob Strachan. 